\title{
THE EXCRETION OF INORGANIC SULPHATES
}

By J. M. HAYMAN, JR., With THE TEChNiCAl ASsistaNCE OF SARA M. JOHNSTON

(From the H. K. Cushing Laboratory of Experimental Medicine in the Department of Medicine of Western Reserve University and the Medical Service of Lakeside Hospital, Cleveland)

(Received for publication February 6, 1932)

Among many estimations of blood concentration and rate of excretion of various substances in the urine, relatively few have been concerned with inorganic sulphates. These, regarded as waste products highly concentrated in the urine, are usually classed with creatinine and many foreign bodies as "no-threshold" substances. Cushny (1926), however, cautioned that "sulphates cannot yet be assigned a definite position as it is uncertain whether they should be placed along with phosphates (low threshold) or among the no-threshold bodies."

After injection of sulphate and creatinine in rabbits, Mayrs (1922) did not find them concentrated by the kidney to exactly the same degree, although the ratios were so close he regarded it as strong evidence that they were excreted by the same process. The slight differences in the concentration ratios he attributed to reabsorption from a glomerular filtrate of small amounts of even these substances during its passage down the tubule. Poulsson (1930a) found the concentration in milligrams per cent of inorganic sulphates in human urine proportional to the degree of concentration of the urine estimated by urine and blood creatinine, concluding that the two substances were eliminated by the same process and concentrated to the same degree; i.e., that sulphates had no threshold, or that little if any diffused back through tubule cells. Ambard (1931), likewise, grouped sulphates with the no-threshold bodies.

White (1923) on the other hand did not find any regular correspondence in concentration ratios of phosphate, sulphate and sugar in phloridzinized dogs and this led him to exclude these from "no-threshold" bodies and to fall back on tubular secretion of sulphate.

Marshall and Crane (1922) found the excretion of sulphate increased by section of the splanchnic nerve, while that of creatinine was little affected. They suggested that possibly some sulphate may be reabsorbed from the glomerular filtrate, or that additional sulphate may be secreted by the tubule cells.

The studies here described were undertaken with the thought of checking the estimated volume of glomerular filtrate according to Rehberg's (1926) creatinine technique by simultaneous determinations of 
serum and urine sulphates. This estimate of the volume of glomerular filtrate depends upon the assumption that no creatinine disappears from the glomerular filtrate or is added to it in the tubules. If then plasma and urine concentrations of creatinine are known, together with the volume of urine excreted per minute, the amount of filtrate required to account for the creatinine eliminated can be estimated by the formula (urine concentration/plasma concentration) $\times$ urine volume. By this calculation, Rehberg found a filtrate of 100-200 cc. per minute, usually 100-150 cc. in normal men. The administration of creatinine by mouth raises the plasma concentration to $5-10 \mathrm{mgm}$. per cent, thus increasing the precision of the colorimetric estimation and diminishing the influence of substances in plasma other than creatinine which give the Jaffe reaction. The presence of such substances in plasma tends to make all estimations of filtrate volume too low. If inorganic sulphates are excreted in the same manner as creatinine, the concentration ratios of the two substances should be the same when determinations are made on the same samples of blood and urine. A concentration ratio for any substance lower than that for creatinine may be attributed to reabsorption or back diffusion in the tubule. It is obvious that any deductions from such estimations depend in large part on the accuracy of the anaiyses of blood sulphates. There is considerable divergence in the values of inorganic sulphates in normal human blood reported in the literature (Table I).

TABLE I

Concentration of inorganic sulphate in normal human blood (recalculated where necessary)

\begin{tabular}{|c|c|c|}
\hline Author and year & Inorganic sulphate & Analytical method \\
\hline & $\underset{\text { per } 100 \mathrm{cc} .}{\operatorname{mgm} .}$ & \\
\hline Denis . . . . . . . . . . . . . . .1921 & $1.5-3$ & Nephelometric \\
\hline Meyer-Bisch . . . . . . . . . 1924 & $14.0-17$ & $\begin{array}{l}\text { Gravimetric on dialysate includes } \\
\text { ethereal sulphate }\end{array}$ \\
\hline Kahn and Postmontier . . 1925 & $2.5-3.8$ & Volumetric \\
\hline Denis and Reed . . . . . . 1926 & $1.05-5.16$ & Nephelometric \\
\hline Loeb and Benedict . . . . . 1927 & $2.1-4.8$ & Gravimetric \\
\hline Wakefield . . . . . . . . . . .1929 & $0.5-1.8$ & Colorimetric \\
\hline Wakefield, Power and & & \\
\hline Keith . . . . . . . . . 1931 & $2.4-5.2$ & Volumetric \\
\hline
\end{tabular}

After a number of experiments with colorimetric methods, the volumetric method of Power and Wakefield ${ }^{1}$ (1931) appeared the most suitable. This consists in the precipitation of inorganic sulphates from a trichloracetic acid filtrate of serum by addition of a solution of benzidine

${ }^{1}$ We are greatly indebted to Dr. Wakefield for furnishing us with the technical procedure of this method before its detailed publication. 
in acetone. The precipitate is separated by centrifugation, washed with acetone, and quantitatively oxidized by potassium dichromate and concentrated sulphuric acid. The excess dichromate is then determined iodometrically. Table II shows its precision in our hands. A single

TABLE II

Control of method

\begin{tabular}{|c|c|c|c|}
\hline \multicolumn{4}{|c|}{ Analysis of solutions of $\mathrm{K}_{2} \mathrm{SO}_{4}$ by method used for blood sulphates } \\
\hline Taken & Found & Taken & Found \\
\hline $\begin{array}{c}\text { mgm. of SO4 } \\
.017 \\
.025\end{array}$ & $\begin{array}{c}m g m . \text { of } S O \\
.015 \\
.012 \\
\\
.025 \\
.022 \\
.021 \\
.035 \\
.037 \\
.035\end{array}$ & $\begin{array}{c}\text { mgm. of SO4 } \\
.049 \\
.056\end{array}$ & $\begin{array}{c}\text { mgm. of SOA } \\
.049 \\
.051 \\
.050 \\
.046 \\
\\
.059 \\
.053 \\
.055 \\
.052\end{array}$ \\
\hline \multicolumn{4}{|c|}{ Recovery of $\mathrm{K}_{2} \mathrm{SO}_{1}$ added to blood } \\
\hline Blood SO, & Added SO, & Calculated & Found \\
\hline $\begin{array}{c}\text { mgm. of SO, per cc. } \\
.043\end{array}$ & $\begin{array}{c}\text { mgm. of SO, per cc. } \\
.017\end{array}$ & $\begin{array}{l}\text { mgm. per cc. } \\
.060\end{array}$ & $\begin{array}{c}\text { mem. per cc. } \\
.058 \\
.057 \\
.059\end{array}$ \\
\hline .037 & .034 & .071 & $\begin{array}{l}.071 \\
.073\end{array}$ \\
\hline .037 & .017 & .054 & $\begin{array}{l}.052 \\
.053\end{array}$ \\
\hline .037 & $.017^{*}$ & .054 & $\begin{array}{l}.054 \\
.058\end{array}$ \\
\hline
\end{tabular}

*.034 mgm. of $\mathrm{PO}_{4}$ per cc. also added.

comparison was made on beef blood of values obtained by this method and by an adaptation of Folin's (1905) urine method to a picric acid filtrate-by titration 11.7 and $11.0 \mathrm{mgm}$. per cent, gravimetrically 11.5 mgm. per cent. To determine whether the sulphate estimated in the trichloracetic acid filtrate was all present in a filterable form, analyses were made of serum and of the fluid obtained by filtration through collodion sacs at $100 \mathrm{~mm}$. Hg pressure. Filtrates gave no reaction for protein with Spiegler's reagent or trichloracetic acid. 


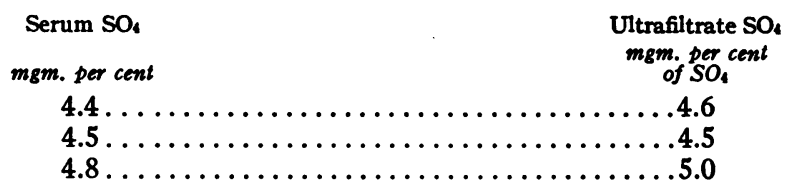

These results led us to believe that we could estimate serum sulphates with sufficient accuracy for the present study.

Most of the subjects were hospital patients without evidence of kidney disease, at rest in bed in the postabsorptive state. The remainder were healthy staff members engaged in light laboratory work during the experiment. An hour after the ingestion of 3 to 7 grams of creatinine the bladder was emptied, and the urine discarded. After an accurately measured time interval, usually an hour, the bladder was again emptied as completely as possible. Blood samples were obtained at the beginning and end of the period of urine collection, allowed to clot and serum separated after centrifuging. All analyses were made on serum. Creatinine was estimated in each sample, the average being assumed to represent the blood level during the period of collection. The same procedure was followed for urea nitrogen in most instances; in a few experiments pooled serum was used. Sulphates were estimated in pooled samples except after injection of sulphates, when of course blood collected at beginning and end of period of urine collection was analysed separately. All analyses were made in duplicate, sulphates usually in triplicate. The analytical methods employed were: serum sulphates by Power and Wakefield's method (1931); urine sulphates by Fiske's (1921) benzidine method after removal of phosphate and Folin's (1905) gravimetric technique; creatinine in serum and urine by Holten and Rehberg's (1931) modification of Folin's method, using a Bürker colorimeter; urea nitrogen in serum and urine by Van Slyke's (1927) manometric method. Known solutions were analyzed at frequent intervals.

After intravenous injection of sulphate, the rate of excretion per minute is proportional to the blood concentration (Table III, Figure 1). The amount of sulphate injected varied from 10-30 grams of $\mathrm{Na}_{2} \mathrm{SO}_{4} \cdot 10 \mathrm{H}_{2} \mathrm{O}$. This was dissolved in 50-150 cc. of distilled water, autoclaved, and injected slowly by gravity or syringe during a period of 15-45 minutes. The subject experienced no discomfort, and no reaction of any kind was detected. Five to ten minutes after the end of the injection, the bladder was emptied and the first blood sample obtained from the opposite arm immediately afterward. An hour later, the first sample of urine and another blood specimen were obtained. From one to four collections of urine, and two to five blood samples were taken in different experiments. The diuresis produced by these injections was only moderate-not as great as that following the ingestion of 1.5 to 2.0 liters of water. The data presented in Table III are from five experiments on two subjects. 
TABLE III

Relation of inorganic sulphate excretion and serum inorganic sulphate

\begin{tabular}{|c|c|c|c|c|c|}
\hline $\begin{array}{l}\text { Serum } \\
\text { SO. }\end{array}$ & $\begin{array}{l}\text { Urine } \\
\text { SO، }\end{array}$ & $\begin{array}{c}\text { Urine } \\
\text { volume }\end{array}$ & $\underset{\text { excreted }}{\mathrm{SO}_{4}}$ & $\begin{array}{c}\text { Concentration } \\
\text { ratio } \\
\text { SO. }\end{array}$ & $\begin{array}{l}\text { Concentration } \\
\text { ratio } \\
\text { creatinine }\end{array}$ \\
\hline $\begin{array}{c}\text { mgm. per } 100 \mathrm{cc} \text {. } \\
\quad * 4.3 \\
\quad * 4.3\end{array}$ & $\begin{array}{c}\text { mgm. per } 100 \mathrm{cc} \text {. } \\
7.4 \\
192.0\end{array}$ & $\begin{array}{c}c c . \text { per minute } \\
19.40 \\
1.61\end{array}$ & $\begin{array}{c}\text { mgm. per minute } \\
1.5 \\
3.1\end{array}$ & $\begin{array}{r}1.7 \\
44.6\end{array}$ & $\begin{array}{l}10.0 \\
68.0\end{array}$ \\
\hline 10.8 & 434.0 & 3.85 & 16.7 & 40.0 & 46.0 \\
\hline 15.1 & 359.0 & 6.18 & 22.2 & 23.8 & 27.4 \\
\hline $\begin{array}{l}19.2 \\
19.3\end{array}$ & $\begin{array}{l}309.0 \\
746.0\end{array}$ & $\begin{array}{l}6.49 \\
2.17\end{array}$ & $\begin{array}{l}20.0 \\
16.2\end{array}$ & $\begin{array}{l}16.1 \\
38.6\end{array}$ & $\begin{array}{l}21.9 \\
77.0\end{array}$ \\
\hline $\begin{array}{l}22.9 \\
23.4\end{array}$ & $\begin{array}{l}745.0 \\
344.0\end{array}$ & $\begin{array}{l}3.37 \\
8.95\end{array}$ & $\begin{array}{l}25.1 \\
30.7\end{array}$ & $\begin{array}{l}32.5 \\
14.7\end{array}$ & $\begin{array}{l}35.4 \\
19.7\end{array}$ \\
\hline 38.1 & 1352.0 & 2.90 & 39.2 & 35.5 & 46.2 \\
\hline 43.4 & 672.0 & 8.0 & 53.8 & 15.5 & 24.3 \\
\hline
\end{tabular}

* No sulphate injected.

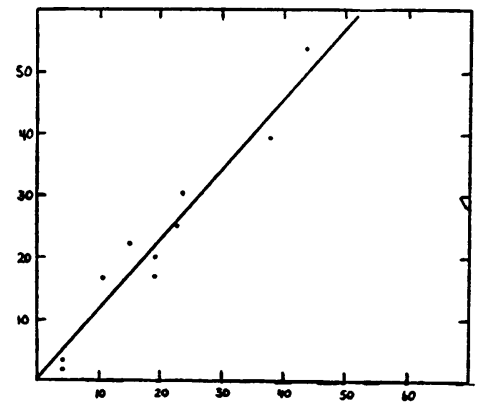

FIG. 1

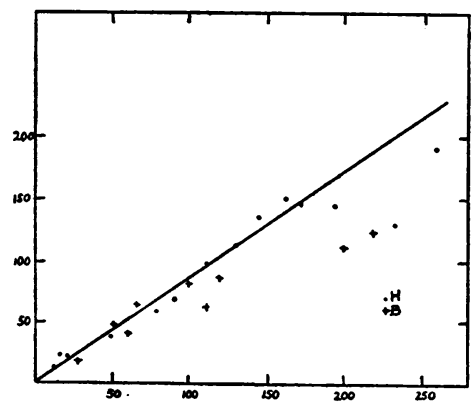

FIG. 2

Fig. 1. Relation of Inorganic Sulphate Excretion and Concentration of InORganic Sulphate in Serum

Abscissae, serum inorganic sulphates, milligrams per cent $\mathrm{SO}_{4}$. Ordinates, milligrams $\mathrm{SO}_{4}$ excreted per minute.

Fig. 2. Relation of Concentration of Inorganic Sulphates in Urine, and Degree of Concentration of the Urine

Abscissae, concentration of creatinine in urine/concentration in serum. Ordinates, urine inorganic $\mathrm{SO}_{4}$ milligrams per cent.

The estimated volume of filtrate can be obtained by multiplying the creatinine concentration ratio by the urine volume. In these experiments, it varied from 109-194 cc. per minute, and was above 150 in six determinations. These are within the range found by Rehberg, but tend 
to be higher than the $100-150 \mathrm{cc}$. per minute usually found under normal conditions.

Under special conditions designed to insure maximum kidney function, a relationship between blood concentration and rate of excretion similar to that found for sulphate has been shown in man for urea by Ambard (1931), McLean (1915), Addis (1922) and others and for creatinine by Cope (1931). Such a linear relation is in accord with glomerular filtration of these substances, but is not evidence of absence of back diffusion-for if there were no back diffusion the rate of excretion of each at a given blood level should be the same, while in fact a higher rate is constantly found for creatinine than for urea (Cope (1931), MacKay and Cockrill (1930)). At high blood sulphate levels, the concentration index of sulphate approaches closely that of creatinine, although never quite equalling it. At normal serum sulphate concentrations, however, the conditions are quite different.

In Table IV are presented the concentration ratio of the urine determined by the quotient (concentration of creatinine in urine/average concentration creatinine in serum during period of urine collection), serum and urine concentrations of urea nitrogen and of inorganic sulphate in normal individuals with various degrees of diuresis. None of the subjects received sulphate. Variations in urine volume were procured by withholding fluid for 12 hours and by ingestion of water. For the greatest urine volumes a liter of water was taken during fifteen minutes, followed by $500 \mathrm{cc}$. every half hour for three or four hours. The estimated volume of filtrate per minute can be obtained from the table by multiplying the creatinine ratio by the urine volume. It varied from 99 to $226 \mathrm{cc}$. per minute. In the 44 determinations, it was below $100 \mathrm{cc}$. once, between 100 and $150 \mathrm{cc}$. twenty-eight times, between 150 and $200 \mathrm{cc}$. eleven times, and above $200 \mathrm{cc}$. four times. This agrees with the findings of Rehberg and of Cope. The data indicate that sulphate is not only concentrated less than creatinine, but with five exceptions, even less than urea. Three of the five instances in which sulphate was more concentrated than urea followed the intramuscular injection of pituitary extract. Neglecting any possible reabsorption or back diffusion of creatinine, the proportion of the filtered sulphate and urea which is excreted can be determined by the formula given by Holten and Rehberg: $E \%=U / P c 100$ where $U=$ urine concentration, $P$ plasma concentration and $c$ the concentration ratio of the urine estimated by creatinine. Such calculation shows an excretion per cent for sulphate from 12.9 to 70 , average 25.8 , and for urea 19.2 to 71.2 , average 44.7 . The sulphate excreted was less than 30 per cent of that in the calculated filtrate in 34 of 44 observations, between 30 and 50 per cent in 7 , and greater than 50 per cent in 3 . The urea excreted was below 30 per cent of that in the calculated filtrate in only 4 instances. The increase in excretion percentage of urea with diuresis 
TABLE IV

Concentration ratios of creatinine, inorganic sulphate, and urea in normal persons

\begin{tabular}{|c|c|c|c|c|c|c|c|c|}
\hline Name & $\begin{array}{c}\text { Urine } \\
\text { volume }\end{array}$ & $\begin{array}{l}\text { Creati- } \\
\text { nine } \\
\text { ratio }\end{array}$ & $\begin{array}{l}\text { Serum } \\
\text { SO، }\end{array}$ & $\begin{array}{l}\text { Urine } \\
\text { SO. }\end{array}$ & $\begin{array}{l}\mathrm{SO}_{4} \\
\text { ratio }\end{array}$ & $\begin{array}{c}\text { Serum } \\
\text { urea } \\
\text { nitrogen }\end{array}$ & $\begin{array}{c}\text { Urine } \\
\text { urea } \\
\text { nitrogen }\end{array}$ & $\begin{array}{l}\text { Urea } \\
\text { ratio }\end{array}$ \\
\hline & $\begin{array}{l}c c \text {. per } \\
\text { minute }\end{array}$ & & $\begin{array}{l}\text { mgm. per } \\
100 \text { cc. }\end{array}$ & $\begin{array}{l}\text { mgm. per } \\
100 \text { cc. }\end{array}$ & & $\begin{array}{l}\text { mgm. per } \\
100 \text { cc. }\end{array}$ & $\begin{array}{l}\text { mgm. per } \\
100 \text { cc. }\end{array}$ & \\
\hline W. & .44 & 286 & 3.8 & 322 & 85.0 & 13.8 & 1332 & 96.5 \\
\hline Buch. & .55 & 221 & 4.6 & 125 & 27.2 & 8.8 & 632 & 71.7 \\
\hline JMH. & .58 & 260 & 3.7 & 192 & 52.0 & 12.2 & 782 & 64.1 \\
\hline JMH. & .64 & 235 & 4.5 & 130 & 29.0 & 19.0 & 1120 & 59.0 \\
\hline JMH. & .66 & 172 & 4.2 & 149 & 35.5 & 11.5 & 380 & $33.0^{*}$ \\
\hline JMH. & .67 & 191 & 4.5 & 145 & 32.2 & & & \\
\hline Buch. & .70 & 199 & 4.6 & 114 & 24.8 & 8.8 & 605 & 68.7 \\
\hline JMH. & .76 & 161 & 4.7 & 150 & 31.9 & 11.7 & 683 & 58.4 \\
\hline Buch. & .83 & 119 & 3.9 & 87 & 22.3 & & & \\
\hline JMH. & .87 & 144 & 4.5 & 136 & 30.2 & & & \\
\hline Buch. & 1.16 & 112 & 3.9 & 64 & 16.4 & & & \\
\hline Tuck. & 1.18 & 159 & 4.4 & 91 & 20.7 & 14.1 & 679 & 48.1 \\
\hline JMH. & 1.23 & 130 & 3.8 & 114 & 30.0 & 13.9 & 655 & 47.1 \\
\hline B. & 1.26 & 128 & 3.6 & 266 & 73.9 & 11.4 & 470 & $41.2^{*}$ \\
\hline Vict. & 1.32 & 85 & 4.9 & 156 & 32.0 & 13.6 & 584 & 43.0 \\
\hline JMH. & 1.33 & 111 & 3.8 & 97 & 25.5 & 13.9 & 588 & 42.3 \\
\hline Buch. & 1.41 & 101 & 3.9 & 82 & 21.0 & & & \\
\hline P. & 1.61 & 68 & 4.3 & 192 & 44.6 & 9.7 & 195 & $20.0^{*}$ \\
\hline JMH. & 1.77 & 90 & 4.5 & 70 & 15.5 & 15.5 & 574 & 37.0 \\
\hline Buch. & 1.79 & 66 & 4.6 & 66 & 14.3 & 10.7 & 378 & 35.3 \\
\hline L. & 1.91 & 66 & 5.1 & 141 & 27.6 & 10.0 & 231 & 23.1 \\
\hline JMH. & 2.10 & 78 & 3.8 & 59 & 15.5 & 13.9 & 452 & 32.5 \\
\hline K. & 2.21 & 61 & 2.9 & 65 & 22.4 & 10.9 & 335 & 30.7 \\
\hline Buch. & 2.52 & 50 & 4.6 & 48 & 10.4 & 11.0 & 292 & 26.6 \\
\hline T. & 2.59 & 54 & 4.0 & 70 & 17.5 & 11.6 & 314 & 27.0 \\
\hline Bailey & 2.70 & 44 & 6.2 & 54 & 8.7 & 15.5 & 366 & 23.6 \\
\hline Buch. & 2.73 & 58 & 4.6 & 38 & 8.3 & 10.7 & 272 & 25.4 \\
\hline JMH. & 3.71 & 48 & 4.5 & 39 & 8.7 & 15.2 & 326 & 21.4 \\
\hline Lutz & 3.80 & 34 & 4.9 & 32 & 6.5 & 16.9 & 259 & 15.3 \\
\hline Buch. & 5.07 & 26 & 4.6 & 16 & 3.5 & 10.3 & 153 & 14.8 \\
\hline Bailey & 5.25 & 23 & 5.3 & 23 & 4.3 & 14.5 & 158 & 10.9 \\
\hline B. & 5.43 & 36 & 3.6 & 91 & 25.3 & 11.4 & 214 & 18.8 \\
\hline L. & 5.68 & 28 & 5.1 & 59 & 11.6 & 9.5 & 126 & 13.3 \\
\hline Lutz & 6.50 & 20 & 4.9 & 29 & 5.9 & 16.0 & 149 & 9.3 \\
\hline JMH. & 7.08 & 21 & 4.0 & 22 & 5.5 & 13.2 & 149 & 11.3 \\
\hline JMH. & 7.15 & 17 & 4.0 & 24 & 6.0 & 13.2 & 128 & 9.7 \\
\hline & 8.30 & 26 & 4.3 & 69 & 16.0 & 8.5 & 142 & 16.7 \\
\hline B. & 11.17 & 16 & 5.1 & 20 & 4.0 & 9.6 & 65 & 6.8 \\
\hline JMH. & 11.30 & 12 & 4.2 & 13 & 3.1 & 11.5 & 92 & 8.0 \\
\hline Bailey & 16.60 & 8 & 5.3 & 9 & 1.7 & 15.2 & 86 & 5.7 \\
\hline & 18.80 & 12 & 5.1 & 20 & 4.0 & 9.4 & 47 & 5.0 \\
\hline & 19.40 & 10 & 4.3 & 7 & 1.6 & 9.7 & 61 & 6.3 \\
\hline Buch. & 24.50 & 9 & 4.7 & 6 & 1.3 & 10.0 & 44 & 4.4 \\
\hline Buch. & 26.60 & 8 & 4.7 & 5 & 1.1 & 9.6 & 37 & 3.9 \\
\hline
\end{tabular}

* After intramuscular injection of pituitrin. 
is not shown for sulphate. The calculated concentration of sulphate in the reabsorbed fluid is always less than the blood concentration. After intravenous injection of sulphate (Table III), the excretion percentage is somewhat higher than at normal blood sulphate levels, reaching a maximum of 92 per cent, but in spite of this the actual amount of sulphate diffusing back from tubule lumen is also greater. The calculated concentration of sulphate in the fluid reabsorbed after sulphate injection is likewise always less than the blood concentration, and the concentration index for sulphate remains within the normal range. A similar limitation of concentrating power for urea was found by Drury (1923) after injection of urea in rabbits. After injection of phosphate its concentration index also approaches that of creatinine, although at normal plasma concentrations it is considerably lower, and according to Havard and Reay (1926) may even fall below one during copious diuresis. We have never encountered urine with a lower sulphate content than blood.

Above a urine volume of about $2 \mathrm{cc}$. per minute the excretion of sulphate is apparently independent of urine volume, the concentration in the urine showing a linear relation to the concentration index of the urine as determined by creatinine (Figure 2). This confirms Poulsson's findings, but if regarded as evidence of lack of back diffusion of sulphate, leads to calculated blood sulphate contents from 12 to 40 per cent of those found by analysis. With low urine volumes and high concentrations, the excretion of sulphate diminishes. This is similar to the findings for urea of Austin, Stillman and Van Slyke (1921), and Möller, McIntosh and Van Slyke (1928). Indeed, when the quantity urine sulphate/blood sulphate $X$ urine volume, representing the number of cubic centimeters of blood whose sulphate content is contained in one minute's urine, is plotted against urine volume, curves of the same type are obtained as those plotted by Möller, McIntosh and Van Slyke for urea excretion (Figure 3).

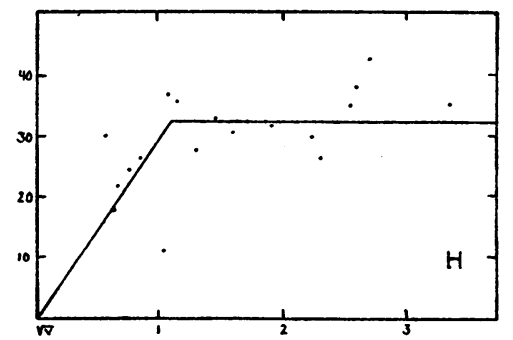

$A$

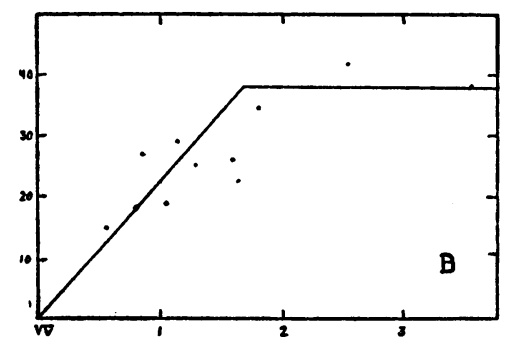

$B$

Fig. 3, $A$ and $B$. Sulphate Excretion Curves from Two Normal Subjects Plotted as Möller, Mcintosh and Van Slyke's

CURVES For UREA EXCRETION

Abscissae, square root of urine volume (cc. per minute). Ordinates, cubic centimeters of blood cleared of inorganic sulphate by one minute's excretion $(U V / B$, where $U=$ concentration inorganic sulphate in urine, $B=$ concentration in serum, and $V=$ cc. urine per minute). 
There is more scattering of the points in these charts than in similar charts for urea excretion. This is probably attributable to the fact that our blood sulphate analyses are not as accurate as the analysis for urea nitrogen. The "augmentation limit," or urine volume above which increased diuresis does not lead to increased excretion, is apparently between 1 and $2 \mathrm{cc}$. per minute, which agrees with the range 1.67 to 2.55 found for urea excretion by Möller, McIntosh and Van Slyke.

The explanation offered by Holten and Rehberg for the relationship of urea excretion and urine volume, namely, that extent of back diffusion is not strictly proportional to volume and concentration of the urine, but is relatively greater with diuresis, may also be offered for sulphate.

The excretion of sulphate in nephritis appears to be of the same nature as in the normal (Table V). When blood sulphates are normal, the concentration ratio of sulphate and creatinine have the usual relationship to each other while when blood sulphates are elevated the sulphate ratio approaches that of creatinine as it does after injection of sulphate in a normal person. We confirm Wakefield, Power and Keith's (1931) observation that serum inorganic sulphates are often elevated before urea nitrogen. This is consistent with the view expressed here that back diffusion of sulphate is usually greater than that of urea. On the other hand, in some patients with uremia and marked elevation of both blood sulphate and urea nitrogen, the concentration ratio and excretion of sulphate may be greater than of urea nitrogen

These studies do not prove the mechanism of excretion of inorganic sulphates. In order to prove that sulphates are eliminated by filtration their presence in glomerular fluid in the same concentration as in blood plasma would have to be established. To prove back diffusion, it would have to be shown that they are less concentrated in the urine than some substance already shown to be eliminated only by glomerular filtration. Evidence of tubular elimination could only be obtained by showing that they were present in urine in greater amount than could possibly be accounted for by glomerular filtration. Convincing evidence of glomerular filtration has been presented by Richards (1929) and his associates, and proof of reabsorption of sugar and chlorides by Wearn and Richards (1924). If belief in glomerular filtration be accepted, creatinine after its ingestion and sulphate can be accepted as present in the filtrate. The increased elimination of creatinine with decreases in plasma proteins (Ni and Rehberg, 1931), the close agreement in concentration ratios of creatinine and sugar in the phloridzinized animal (Poulsson, 1930b), and the fact that the volume of glomerular filtrate necessary to account for the elimination of creatinine by filtration alone is not inconsistent with the area of filtering surface (Vimtrup, 1928) and observed rates of passage of fluid through capillary walls (Landis, 1927), makes it unnecessary to fall back on tubular secretion to account for the elimination of creatinine. 


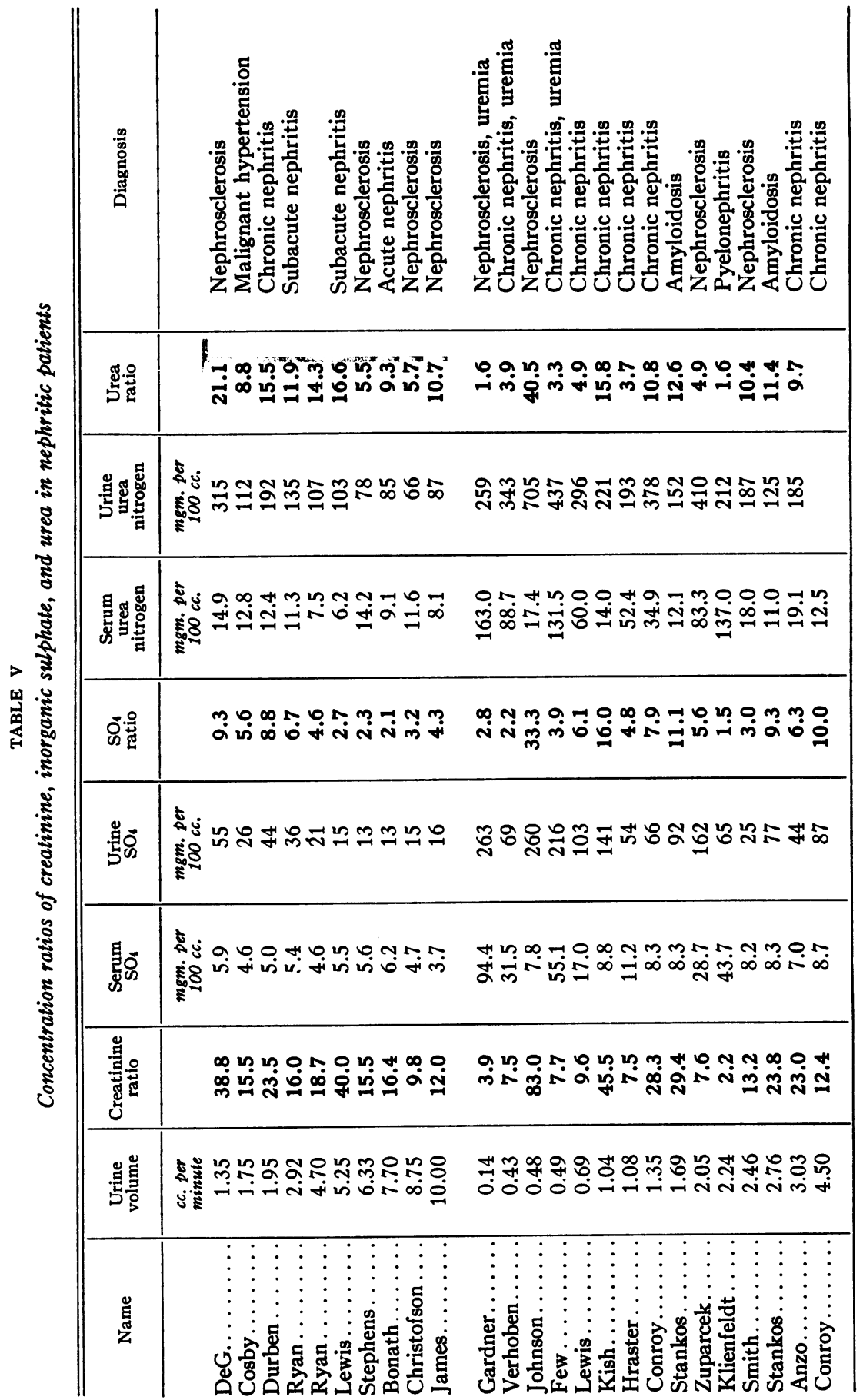


If inorganic sulphate is believed to be present in the glomerular filtrate, rates of excretion less than for creatinine seem most readily accounted for by diffusion of some sulphate ion from the lumen of the tubules into tubule cells during the process of concentration of the urine by the active reabsorption of water. The elimination of such substances as urea and sulphate depends in part on the capacity of the tubule cells to resist this back diffusion-to preserve a high concentration on the lumen side and a low one on the capillary side. Our results indicate that this power is usually greater for urea than for sulphate.

\section{CONCLUSION}

1. Inorganic sulphates are less concentrated by the human kidney than creatinine, and usually less concentrated than urea. In accordance with a belief in filtration and reabsorption, this is regarded as evidence that some sulphate diffuses back through tubule cells.

2. After intravenous injection of sulphate, the concentration ratio approaches that of creatinine.

3. In nephritis with elevated serum sulphate, the excretion resembles that in a normal individual after injection of sulphate.

\section{BIBLIOGRAPHY}

Addis, T., Arch. Int. Med., 1922, xxx, 378. Renal Function and the Amount of Functioning Tissue.

Ambard, L., Physiologie Normale et Pathologique des Reins. 1931, 3rd ed., Masson et Cie, Paris.

Austin, J. H., Stillman, E., and Van Slyke, D. D., J. Biol. Chem., 1921, xlvi, 91. Factors Governing the Excretion Rate of Urea.

Cope, C. L., Quart. J. Med., 1931, xxiv, 567. The Excretion of Creatinine by the Human Kidney in Health and in Nephritis.

Cushny, A. R., The Secretion of the Urine. 1926, 2nd ed., Longmans, Green and Co., Ltd., London.

Denis, W., J. Biol. Chem., 1921, xlix, 311. Sulfates in Blood.

Denis, W., and Reed, L., J. Biol. Chem., 1926, lxxi, 191. Methods for the Determination of Some of the Nonprotein Sulphur Compounds of Blood.

Drury, D. R., J. Biol. Chem., 1923, lv, 113. The Rate of Urea Excretion. VI. The Effect of Very High Blood Urea Concentrations on the Rate of Urea Excretion.

Fiske, C. H., J. Biol. Chem., 1921, xlvii, 59. The Determination of Inorganic Sulfate, Total Sulfate, and Total Sulphur in Urine by the Benzidine Method.

Folin, O., J. Biol. Chem., 1905, i, 131. On Sulphate and Sulphur Determinations.

Havard, R. E., and Reay, G. A., Biochem. J., 1926, xx, 99. Note on the Excretion of Phosphate during Water Diuresis.

Holten, C., and Rehberg, P. B., Acta med. Scandinav., 1931, lxxiv, 479. Studies on the Pathological Function of the Kidneys in Renal Disease, Especially in Bright's Disease. 
Kahn, M., and Postmontier, R. S., J. Lab. and Clin. Med., 1925, x, 317 . On the Nonprotein Sulphur of the Blood.

Landis, E. M., Am. J. Physiol., 1927, 1xxxii, 217. Micro-Injection Studies of Capillary Permeability. II. The Relation between Capillary Pressure and the Rate at Which Fluid Passes through the Walls of Single Capillaries.

Loeb, R. F., and Benedict, E. M., J. Clin. Invest., 1927, iv, 33. Inorganic Sulphates in Human Blood.

Marshall, E. K., and Crane, M. M., Am. J. Physiol., 1922, 1xii, 330. Studies on the Nervous Control of the Kidney in Relation to Diuresis and Urinary Secretion. VI. The Effect of the Unilateral Section of the Splanchic Nerve on the Elimination of Certain Substances by the Kidney.

Mayrs, E. B., J. Physiol., 1922, lvi, 58. The Relative Excretion of Urea and Some Other Constituents of the Urine.

MacKay, E. M., and Cockrill, J. R., Am. J. Physiol., 1930, xciv, 220. The Regulation of Renal Activity. XII. The Relation of the Rate of Creatinine Excretion in the Urine to the Plasma Concentration.

McLean, F. C., J. Exp. Med., 1915, xxii, 212. The Numerical Laws Governing the Rate of Excretion of Urea and Chlorides in Man. I. An Index of Urea Excretion and the Normal Excretion of Urea and Chloride.

Meyer-Bisch, R., Biochem. Ztschr., 1924, cl, 23. Über den Schwefelsäuregehalt verschiedener Körperflüssigkeiten unter normalen und pathologischen Zuständen.

Möller, E., McIntosh, J. F., and Van Slyke, D. D., J. Clin. Invest., 1928, vi, 427. Studies of Urea Excretion. II. Relationship between Urine Volume and the Rate of Urea Excretion by Normal Adults.

Ni, Tsang-G., and Rehberg, P. B., J. Physiol., 1931, lxxi, 331. On the Influence of Posture on Kidney Function.

Poulsson, L. T., Ztschr. f. d. ges. exper. Med., 1930a, 1xxi, 577. Über die Wirkung des Pituitrins auf die Wasserausscheidung durch die Niere.

Poulsson, L. T., J. Physiol., 1930b, lxix, 411. On the Mechanism of Sugar Elimination in Phlorrhizin Glycosuria. A Contribution to the Filtration-Reabsorption Theory on Kidney Function.

Power, M. H., and Wakefield, E. G., Proc. Staff Meetings Mayo Clinic, 1931, vi, 401. A Method for the Determination of Inorganic Sulphate in Blood Serum.

Rehberg, P. B., Biochem. J., 1926, xx, 447 and 461. Studies on Kidney Function. I. The Rate of Filtration and Reabsorption in the Human Kidney. II. The Excretion of Urea and Chloride Analyzed According to a Modified Filtration-Reabsorption Theory.

Richards, A. N., Methods and Results of Direct Investigations of the Function of the Kidney. Williams and Wilkins Co., Baltimore, 1929.

Van Slyke, D. D., J. Biol. Chem., 1927, lxxiii, 695. Determination of Urea by Gasometric Measurement of the Carbon Dioxide Formed by the Action of Urease.

Vimtrup, B., Am. J. Anat., 1928, xli, 123. On the Number, Shape, Structure, and Surface Area of the Glomeruli in the Kidneys of Man and Mammals.

Wakefield, E. G., J. Biol. Chem., 1929, 1xxxi, 713. The Colorimetric Determination of Total and Inorganic Sulphates in Blood Serum, Urine and Other Body Fluids. 
Wakefield, E. G., Power, M. H., and Keith, N. M., J. Am. Med. Assoc., 1931, xcvii, 913. Inorganic Sulphates in the Serum in Early Renal Insuffciency.

Wearn, J. T., and Richards, A. N., Am. J. Physiol., 1924, 1xxi, 209. Observations on the Composition of Glomerular Urine with Particular Reference to the Problem of Reabsorption in the Renal Tubules.

White, H. L., Am. J. Physiol., 1923, lxv, 537. Studies on Renal Tubule Function. III. Observations on the Excretion of Sulphate, with a Modified Technique for the Determination of Inorganic Sulphate in Blood or Plasma. 